\title{
Polypore survey of Finland 1. Introduction
}

\author{
TUOMO NIEMELÄ
}

\begin{abstract}
NIEMELÄ, T. 1982: Polypore survey of Finland 1. Introduction. - Karstenia 22: $21-26$.

This is an introduction to a series of papers devoted to the mapping of the polypore species occurring in Finland. The survey is based on the Finnish national uniform grid system (Grid $27^{\circ} \mathrm{E}$ ), whose unit is $10 \times 10 \mathrm{~km}$. For each distribution map all the material available in public Finnish herbaria has been consulted. It is planned to publish the maps at irregular intervals. The principles of the mapping are presented and the biogeography of Finland briefly discussed. The names are given of the most important indigenous and cultivated tree species infected by polypores in Finland.
\end{abstract}

Tuomo Niemelä, Department of Botany, University of Helsinki, Unioninkatu 44, SF00170 Helsinki 17, Finland

\section{Foreword}

This plan to map the distributions of the Finnish polypores was prompted by several considerations. Firstly, it has long been evident that the information on the occurrence of many species is fragmentary and in some cases erroneous. It was felt necessary to make a revision which would be based solely on sources verifiable by the authors: the existing herbarium material and personal observations.

Secondly, the numbers of specimens preserved in the Finnish herbaria are more or less adequate for a rough survey, and there is no hope in the foreseeable future of obtaining extensive new collections from the at present unstudied areas of Finland. Therefore, there is no reason to postpone the plan.

Thirdly, the technical facilities for such mapping are now better than before. The use of the uniform grid system has simplified the work, without seriously diminishing the accuracy of the resulting maps. The species occurring in the country are now known well enough for reliable identification.

Documentation of the present state of knowledge on the distribution of polypores will be welcome in many sectors of botanical and forest research, especially in a country like Finland, whose economy and welfare depends predominantly on forestry.

The distribution maps will mainly be published under the title 'Polypore survey of Finland'. Each article will normally deal with a complete genus, family (Jülich 1981), or other taxonomic entity, so that all the distributional information concerning a certain group will be available in a single paper. The sequence in which the papers are issued will not have any relation to the systematic position of the groups.
Some of the maps will be published separately, or have already been so (Kotiranta \& Niemelä 1981). The general terms used are presented in this Introduction and will not be repeated in the subsequent survey articles.

The work was started in 1980 , with the planning and elaboration of the working routine. By the end of 1981 , ca. 6000 specimens had been studied and documented, and maps had been completed, or nearly so, for over 50 species. During this period of two years financial support from the Academy of Finland enabled Mr. Heikki Kotiranta, M.Sc., to devote himself to the survey. The rate at which the articles are issued in future will depend mainly on the financial circumstances.

In addition, collecting trips were made in the field, mainly in the lesser known northern areas.

At least for the first of the forthcoming parts of the series the division of labour was as follows: Heikki Kotiranta performed most of the herbarium studies, transferred the information to the distribution maps and made the host lists. The written parts are mostly by Tuomo Niemelä, who also studied or confirmed the critical material and supervised the whole project.

\section{The research area}

Finland is situated roughly between the latitudes of $60^{\circ}$ and $70^{\circ} \mathrm{N}$, i.e., as far north as the southern half of Greenland. The climate is rather favourable, however, and Finland is covered by woody vegetation up to the northernmost parts. In most parts the climate is slightly oceanic or intermediate: slightly continental areas can be found only in innermost Lapland 
(between 68 and $69^{\circ} \mathrm{N}$ ) and in the easternmost corner of Central Finland (Ahti et al. 1968), where the continental effect is, however, less marked. The length of the growing season decreases from south to north by about 3 months (from over 180 to 90 days, threshold $+5^{\circ} \mathrm{C}$; Tuhkanen 1980). This marked reduction of the growing season seems to cause no obvious limitations to the distribution of the majority of the fungi, especially because there is sufficient rainfall during most of the year. The important summer precipitation in May-September varies from over $300 \mathrm{~mm}$ in the southern and eastern parts to $250-200 \mathrm{~mm}$ in the north. Climate diagrams from different parts of the country have been published by Walter \& Lieth (1967), and the climatic conditions and their effects on the vegetation have been discussed extensively by Tuhkanen (1980). For a general geographical survey of Finland, see Sømme (1968).

Finland is for the most part a lowland; one third of its area lies below $100 \mathrm{~m}$, two thirds below $200 \mathrm{~m}$ and only a little more than one tenth exceeds $300 \mathrm{~m}$. The higher areas are in the north, which slightly steepens the vegetational zonal gradient along the south-north axis. No permanent snow caps occur even on the northern mountains, and there is no permafrost, except in some of the northernmost bogs.

Finland has traditionally been divided into biological provinces (Heikinheimo \& Raatikainen 1971, 1981), with standard abbreviations (Fig. 1). These province abbreviations have been used in the present series of papers in listing the occurrences of fungi on different host tree species. Some commonly used regional names are also presented in Fig. 1.

\section{Vegetation and trees}

The whole of Finland belongs to the Boreal zone (Hämet-Ahti 1981), also called the zonobiome of the Cold-Temperate Boreal climate (Walter 1979), and roughly corresponding to the taiga of Soviet authors. This zone is divided into subzones, mostly on the basis of vegetational criteria (Fig. 2): Southern boreal, Middle boreal and Northern boreal (Ahti et al. 1968). Further, the south-western coastal strip of Finland belongs to the Hemiboreal subzone, which is transitional between the Boreal and the Temperate zone. Some elevated northern areas of Lapland lie in the Orohemiarctic or Oroarctic altitudinal belts, but no lowland Arctic areas occur in Finland.

This biogeographical position is clearly reflected in the forests and the distribution of different trees. The northern limits of distribution for some important forest tree species are given in Fig. 2. These are limits for the native occurrences: for instance, Acer platanoides and Quercus robur reach much farther north as cultivated park trees. For a concise review of the forest vegetation in Finland, the reader is referred to

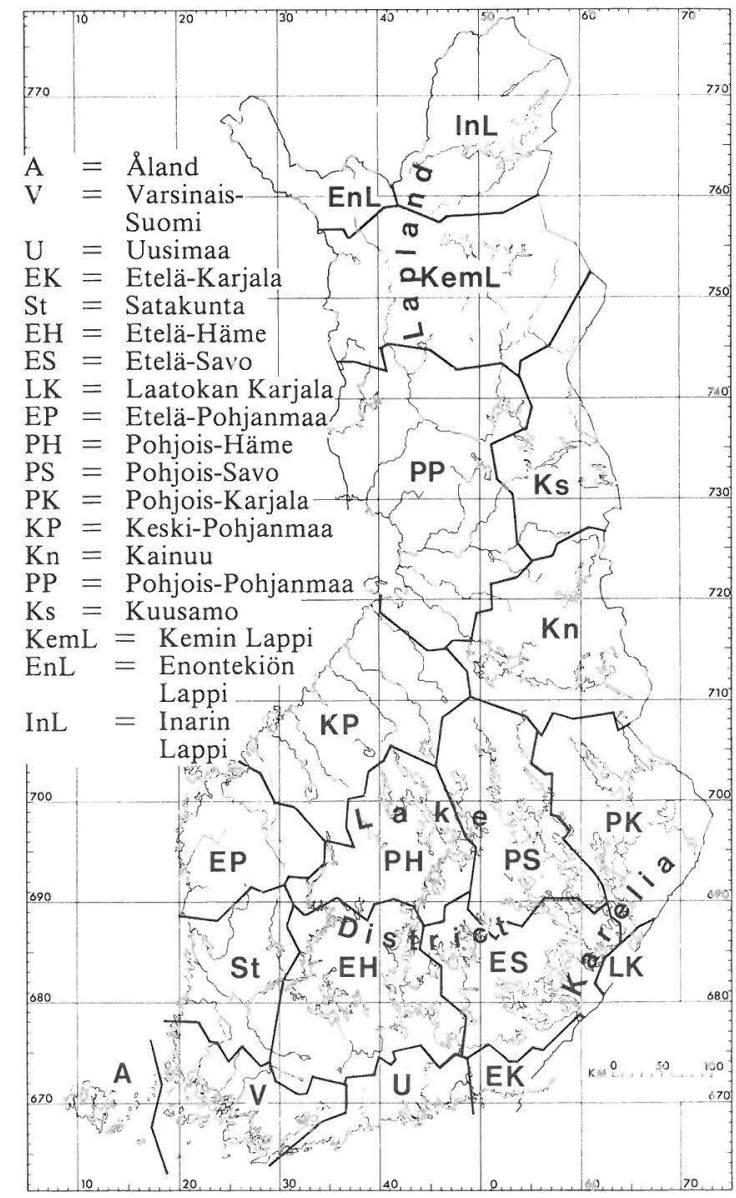

Fig. 1. The biological provinces and common names of some areas in Finland.

Sømme (1968). A classification of the Fennoscandian forest vegetation has been proposed by KiellandLund (1973), whose paper also contains important references for further reading.

The forests of Finland are rather poor in species compared with many other parts of the Eurasian Boreal zone. The only species forming pure coniferous stands are Picea abies and Pinus sylvestris. It is noteworthy that Abies and Larix species are not indigenous to the area, though the native ranges of Abies sibirica and Larix sibirica reach rather close to the eastern border of Finland and the species are hardy and widespread in cultivation in the country. The same applies to Pinus cembra var. sibirica. In Lapland there is a transition from Picea abies ssp. abies (SW parts) to ssp. obovata (NE parts), which may explain some distributions of the spruce-rotting fungi, though such cases have not been examined closely.

In the Hemiboreal subzone, in particular, there occur small-scale pure native stands of Quercus robur, 
Fraxinus excelsior (especially in Åland), Ulmus glabra and Tilia cordata. Corylus avellana forms thickets in forests at an early stage of succession. The fungus flora of such woodland is markedly southern, but the absence of some important tree species (Carpinus betulus and in particular Fagus sylvatica) makes it differ clearly from that in the forests of northern Central Europe.

The most important hardwood genus in Finland is Betula. Birches often form pure stands in forests at an early stage of succession. The species of Betula growing as true trees are $B$. pubescens and $B$. pendula, both common almost all over the country. These two hosts are only very seldom specified in the herbarium labels of the birch-dwelling fungi, and therefore it is impossible to make any comparisons between them. In Lapland they are gradually replaced by the mountain birch (Betula pubescens ssp. tortuosa). This is a low and many-stemmed race, which forms extensive, permanent and pure stands, especially on the fjeld slopes above the coniferous tree-line, and composes the upper timberline below the Orohemiarctic and Oroarctic mountain tops. The sole climax-stage timberline-forming tree in Lapland is the mountain birch (Hämet-Ahti 1981), and not for instance Pinus mugo (as in the Central European mountains), Larix (as in most areas of northern Siberia) or any other conifer. High oceanity has generally been regarded as the reason for this. The mountain birch is an important host for some northern polypore species.

The only native species of the aspen genus is Populus tremula, though many poplar species and hybrids thrive as park trees. Aspen can form small-scale pure stands vegetatively, but occurs as solitary trees in all kinds of moist forests up to the climax stage. It harbours some very specialized parasitic fungi.

Many other hardwood species are important as hosts, though less abundant. Their names will occur regularly in the host lists of the future papers in this series, and some are introduced in Fig. 2. Also worthy of mention are the alders (Alnus incana and A. glutinosa), locally common in moist brook- and lake-side forests. Alnus incana also occurs fairly commonly in drier forest sites, especially in southeastern Finland, mostly at the edges of cultivated fields. This is an effect of the earlier extensive shifting cultivation in that region. Both species of alder serve as hosts for a vast variety of polypores. They differ markedly from each other, both ecologically and as host trees for fungi. In the herbarium labels, however, they have often been identified only by genus, which masks many of these differences. In the provinces PP-Ks and farther north, $A$. incana ssp. incana is replaced by ssp. kolaensis.

Park trees form an important group of hardwood hosts. They are mostly of foreign origin, and the climatic and environmental stresses make them particularly susceptible to wood-rotting fungi. Particularly

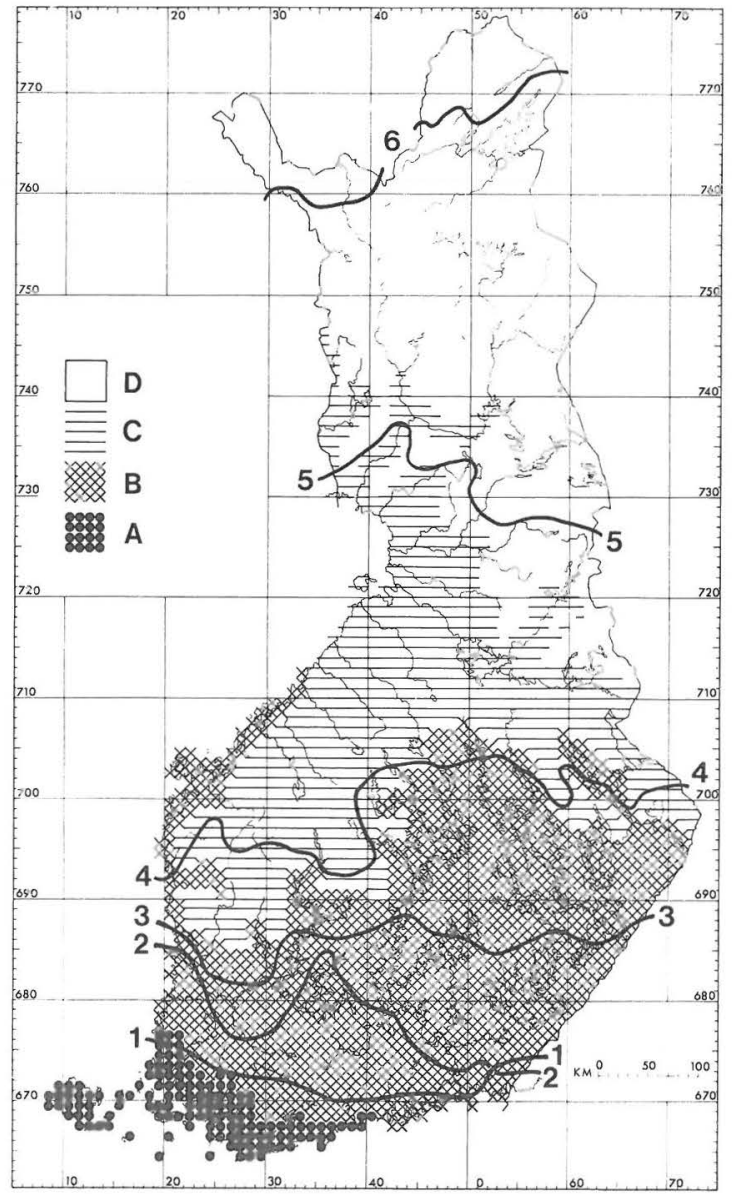

Fig. 2. Vegetational subzones and the occurrence of some important forest trees in Finland. A) Hemiboreal subzone, B) Southern boreal subzone, C) Middle boreal subzone, D) Northern boreal subzone with its Orohemiarctic and Oroarctic outliers (Ahti et al. 1968).

Northern limits of some forest trees: 1) Quercus robur, 2) Fraxinus excelsior, 3) Acer platanoides, 4) Tilia cordata, 5) Alnus glutinosa, 6) Picea abies. Trees distributed throughout Finland, or nearly so, are Alnus incana, Betula pendula, $B$. pubescens, Pinus sylvestris, Populus tremula, Prunus padus, Salix caprea and Sorbus aucuparia (Kalliola 1973).

abundant in southern Finnish parks and boulevards, they are too numerous to be listed here. Kallio (1966) has enumerated some cultivated trees and shrubs in Finland, and presented distribution maps.

The host names are according to Hämet-Ahti et al. (1981), Tutin et al. (1964-1980), and the author abbreviations will not be repeated here. The vegetational zonation and the factors responsible for it are discussed extensively by Ahti et al. (1968), Kalliola (1973) and Hämet-Ahti (1981). Distribution maps of indigenous trees in Finland are presented by Hustich (1961), Meusel (1965, 1978), Hultén (1971), Kalliola (1973) and Jalas \& Suominen $(1973,1976)$. 


\section{Mapping}

The distribution maps are based on the material preserved in the public Finnish herbaria: H, HFR, TUR, KUO and OULU (abbreviated as in Holmgren et al. 1981). The herbarium H (University of Helsinki) includes the collections of P.A. Karsten and Matti Laurila, and the reference herbaria of Tuomo Niemelä (abbreviated as T.N.) and Heikki Kotiranta (H.K.) have also been used. Data from notebooks or corresponding information has been accepted in only a few cases, and then always after critical consideration. Records in the literature have been excluded, except in a few cases concerning some rare and easily identified species. The inclusion of such records has been indicated in the maps.

Every specimen referred to in the maps has been examined by either Tuomo Niemelä or Heikki Kotiranta, which is testified by the words 'Polypore survey of Finland' stamped on the envelope or the identification label. A data card has been written out for every specimen studied: these are preserved in the Department of Botany, University of Helsinki.

The distibution maps have been prepared according to the Finnish national uniform grid system (see Heikinheimo \& Raatikainen 1971, 1981), in which the squares have an area of $10 \times 10$ kilometres. This grid division is presented elsewhere, e.g., in a special edition of the GT Road Map of Finland (1: 200 000), published in 19 parts from 1976 onwards, and in the newer sheets of the Topographical Map (1: 50 000). These two maps are published and distributed by the National Board of Survey (Maanmittaushallitus), Helsinki.

\section{The distribution maps}

It cannot be too strongly emphasized that the distributional maps give only fragmentary pictures of the true occurrences of the species. Some areas of the country are virtually undocumented or covered only by a sparse network of observations: the provinces of $\mathrm{EP}, \mathrm{KP}, \mathrm{PH}, \mathrm{PS}$ and PK , and many areas in Lapland belong to this group (cf. Fig. 3).

The existing collections show that attention has clearly been focused on certain areas. The best documented parts of the country are in the south: the environs of Helsinki and Turku in particular, and the provinces of $\mathrm{A}, \mathrm{V}, \mathrm{U}, \mathrm{EK}$, and $\mathrm{EH}$ in general. Wellstudied areas in northern Finland are the district north of Oulu (especially the Pisavaara National Park SW of Rovaniemi town), Ks (especially the Oulanka National Park), western KemL (Pallas-Ounas National Park) and northern InL (around the Kevo Subarctic Research Station). The concentration of collecting activity in certain areas is evident from any map of a commoner, widespread polypore species.

This uneven documentation creates some difficul-

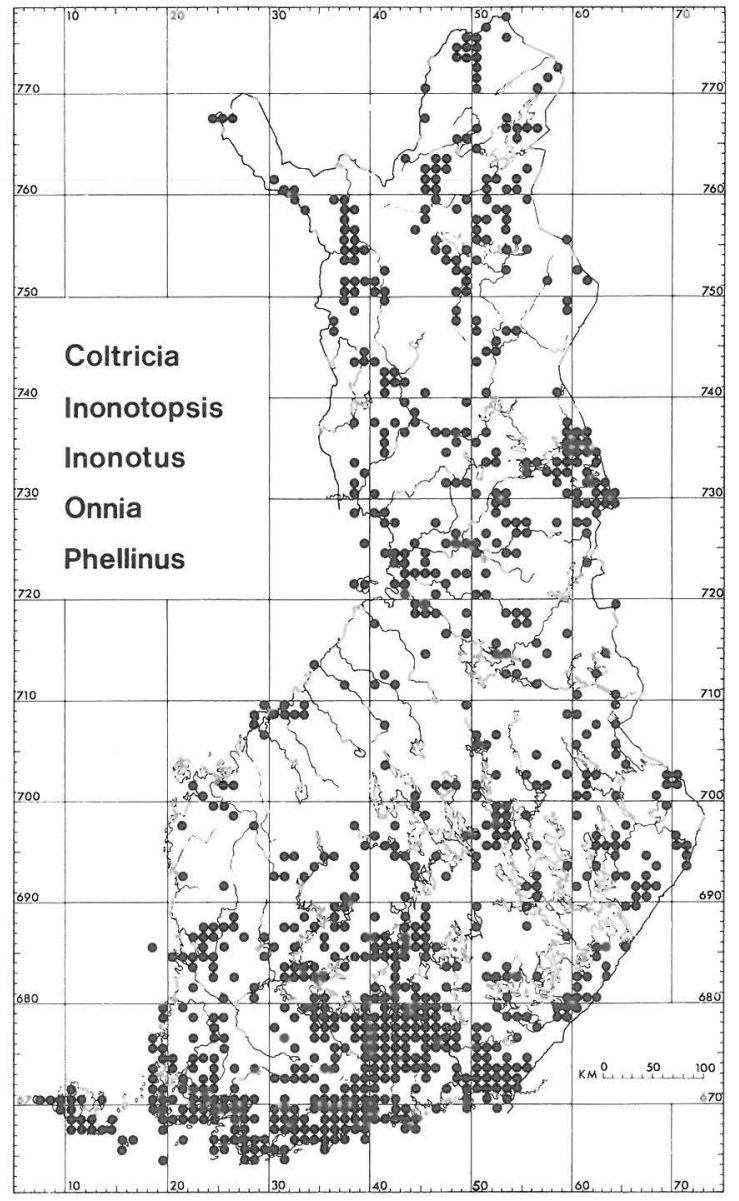

Fig. 3. The intensity of polypore collecting in different parts of Finland. The map consists of the superimposed distribution maps of Coltricia, Inonotopsis, Inonotus, Onnia and Phellinus, altogether 29 species (Niemelä \& Kotiranta 1982, 1983). Many of the species occur in virtually all parts of the country.

ties in the correct interpretation of the distribution maps. As collecting activity is stronger in the south, any map showing a relatively even pattern of dots over the whole country in fact indicates that the species in question is distinctly commoner in the north. For instance, the maps of Phellinus pini and P. chrysoloma (presented in Niemelä \& Kotiranta 1982) show differences in this respect. P. pini is clearly southern in its distribution, fairly common in S and C Finland, becoming very rare only in Lapland. $P$. chrysoloma, its spruce-dwelling counterpart, shows a distinct northern emphasis in its distribution. It is fairly rare to scattered in S and C Finland, but he number of collections from the sparsely studied north shows the species to be very common there.

Generally speaking, the absence of records from S Finland is more significant than the absence of records from N Finland. 


\section{Other information presented}

The maps will be accompanied by brief discussions of each species. These notes will follow a general scheme, beginning with a list of host trees. Some difficulties are caused by incomplete data concerning the hosts on the herbarium labels: Sometimes the host has been indicated accurately, sometimes only the genus is given or the host is not specified.

In the host lists the genera are presented in the order of their frequency in the collections. So these lists may also be regarded as rough host preference lists for the polypores as they occur in Finland. If the host tree genus is represented by only one species, the specific name follows directly after the generic name. More often, however, the genus is listed alone, and under it follow the species in order of frequency. In these cases the numerical information following the generic name refers to all the collections made from that genus, whether the host was identified to species or not. The number following a particular species (in italics) is its percentage of the total material with host indication studied.

In calculating these percentages, collections with unidentified hosts were excluded, but these were of course included in the numbers of specimens examined.

The numbers indicating the percentages of the collections found on different hosts are arranged in five columns. The first shows the values for the whole of Finland. The other columns give the values for four groups of biological provinces, viz. A-U representing southern Finland, EK-PK southern central, KP-PP northern central, and Ks-InL northern Finland. Very roughly, the first group (A-U) corresponds to the Hemiboreal subzone, the second to the Southern boreal, the third to the Middle boreal and the fourth to the Northern boreal subzone.

The symbol + in the host lists indicates a single record; if the collections are few it may represent a considerable proportion.

The host lists are followed by some general notes on each species. Firstly, a verbal estimate is given of the frequency of occurrence. These estimates are based on personal field observations and are expressed in the following terms: very common, common, fairly common, scattered, fairly rare, rare, very rare. Although inaccurate and subject to personal under- or overestimating, this supportive rating was felt to be useful. In the herbaria the common, large-sized or resupinate species are often represented by fewer specimens than they should be, collecting activity being focused on relatively small-sized, bright-coloured fruit bodies, mainly of rare species. This personal rating also serves to correct misleading impressions made by disproportionately numerous collections from rare and exotic host trees in parks, as opposed to those from the indigenous hosts in natural forests.
The discussion ends with an outline of the general ecology of the polypore species and an estimate of its economic importance. These are characters which often differ markedly from those in Central Europe.

Acknowledgements. The start of this mapping project was possible by a two-year grant from the Academy of Finland. This Introduction was revised by Prof. Jaakko Jalas and Prof. Leena Hämet-Ahti (both from Helsinki), who thus gave a mycologist the reassurance needed in tackling a less familiar topic. Many helpful suggestions were also made by Prof. Teuvo Ahti (Helsinki). The curators of the Finnish herbaria are thanked for numerous extensive loans. Unless indicated to the contrary, Mrs. Anna A. Damström, M.A., revised the English of this and the following papers.

\section{References}

Ahti, T., Hämet-Ahti, L. \& Jalas, J. 1968: Vegetation zones and their sections in northwestern Europe. - Ann. Bot. Fennici 5: 169-211.

Hämet-Ahti, L. 1981: The boreal zone and its biotic subdivision. - Fennia 159(1): 69-75.

Hämet-Ahti, L., Jalas, J. \& Ulvinen, T. 1981: Suomen alkuperäiset ja vakiintuneet putkilokasvit. Third edition. Helsingin Yliopiston Kasvit. Lait. Monist. 71: 1-112.

Heikinheimo, O. \& Raatikainen, M. 1971: Paikan ilmoittaminen Suomesta talletetuissa biologisissa aineistoissa. The recording of localities of biological finds in Finland. - Ann. Entomol. Fennici 37(1a): 1-27.

- 1981: Ruutukoordinaattien ja paikannimien käyttö Suomessa. Grid reference and names of localities in the recording of biological finds in Finland. - Not. Entomol. 61: $133-154$.

Holmgren, P., Keuken, W. \& Schofield, E. 1981: Index herbariorum 1. The herbaria of the world. $-452 \mathrm{pp}$. Utrecht etc.

Hultén, E. 1971: Atlas över växternas utbredning i Norden. Second edition. - $531 \mathrm{pp}$. Stockholm.

Hustich, I. 1961: Forest and tree lines in northernmost Fennoscandia. - Arch. Soc. Zool. Bot. Fenn. Vanamo 16 (Suppl.): $111-113$.

Ilvessalo, Y. 1960: Suomen metsät kartakkeiden valossa The forests of Finland in the light of maps. - Metsäntutkimusl. Julk. 52(2): 1-70.

Jalas, J. \& Suominen, J. (eds.) 1973: Atlas Florae Europaeae 2. -40 pp. Helsinki.

- 1976: Atlas Florae Europaeae 3. - 128 pp. Helsinki.

Jülich, W. 1981: Higher taxa of Basidiomycetes. - 485 pp. Vaduz.

Kallio, T. 1966: Koristepuiden ja -pensaiden levinneisyydestä ja menestymisestä Suomessa. Über Verbreitung und Gedeihen von Zierbäumen und -sträuchern in Finnland. - Ann. Agric. Fenn. 5 (Suppl. 1): 1-107.

Kalliola, R. 1973: Suomen kasvimaantiede. - 308 pp. Porvoo \& Helsinki.

Kielland-Lund, J. 1973: A classification of Scandinavian iorest vegetation for mapping purposes. - IBP i Norden 11: $173-206$

Kotiranta, H. \& Niemelä, T. 1981: Composition of the polypore communities of four forest areas in southern Central Finland. - Karstenia 21: 31-48.

Meusel, H. (ed.) 1965: Vergleichende Chorologie der zentraleuropäischen Flora. Karten 1. -258 pp. Jena.

- 1978: Vergleichende Chorologie der zentraleuropäischen Flora. Karten 2. - Pp. 259-421. Jena.

Niemelä, T. \& Kotiranta, H. 1982: Polypore survey of Finland 2. The genus Phellinus. - Karstenia 22: 27-42

- 1983: Polypore survey of Finland 3. The genera Coltricia, Inonotopsis, Inonotus and Onnia. - Manuscript. 
Sømme, A. (ed.) 1968: A geography of Norden. New edition. - 356 pp. Oslo.

Tuhkanen, S. 1980: Climatic parameters and indices in plant geography. - Acta Phytogeogr. Suec. 67: 1-110.

Tutin, T. et al. (eds.) 1964-1980: Flora Europaea 1-5. Cambridge.
Walter, H. 1979: Vegetation of the Earth and ecological systems of the geo-biosphere. Second edition. $-274 \mathrm{pp}$. New York, Heidelberg \& Berlin.

Walter, H. \& Lieth, H. 1967: Klimadiagramm-Weltatlas. Unnumbered loose-leaf maps and diagrams. Jena.

Accepted for publication

on April 28, 1982 